Цьљенова Е. Б., Данчинова М. Д., Художественный мир произведений А. С. Пушкина «Повести Белкина» в осмыслении юного читателя

УДК 821.161 .1

DOI: 10.18101/2305-459X-2020-2-61-65

\title{
ХУДОЖЕСТВЕННЫЙ МИР ПРОИЗВЕДЕНИЯ А. С. ПУШКИНА «ПОВЕСТИ БЕЛКИНА» В ОСМЫСЛЕНИИ ЮНОГО ЧИТАТЕЛЯ
}

\author{
(C) Цыденова Елена Буянтуевна \\ магистрант, \\ Бурятский государственный университет имени Доржи Банзарова \\ Россия, 670000, г. Улан-Удэ, ул. Смолина, 24а \\ tsdenova@mail.ru

\section{(C) Данчинова Мария Даниловна} \\ кандидат филологических наук, доцент, \\ Бурятский государственный ниверситет имени Доржи Банзарова \\ Россия, 670000, г. Улан-Удэ, ул. Смолина, 24а \\ marinadan67@mail.ru
}

Аннотация. В статье рассматривается художественный мир произведения А. С. Пушкина «Повести Белкина». Раскрывается своеобразие пространственновременной картины мира через композиционную взаимосвязь повестей, собственно образной системы, сюжетной линии. Видение мира раскрывается через форму повествования. В этом плане писатель выходит на грань общечеловеческих основ. С позиции художника в жизни человека все не случайно. Цепь взаимосвязанных событий влияет на жизнь человека во всех отношениях: это различные события в обществе; неожиданные, казалось бы, встречи с людьми; нарушения многих этических норм, которые влияют на судьбу человека; рассмотрение многих ценностей, заложенных каждым народом в религиозно-культурные пласты. Автор художественно предостерегает людей от бездуховного, потребительского отношения ко всему миру. Произведение писателя призывает задуматься о серьезных последствиях нравственного падения людей в обществе, эгоистическом отношении людей друг к другу.

Ключевые слова: композиция, картина, мир, герой, пространство, образ, система.

\section{Для цитирования:}

Цыденова Е. Б., Данчинова М. Д., Художественный мир произведений А. С. Пушкина «Повести Белкина» в осмыслении юного читателя // Вестник Бурятского государственного университета. Язык. Литература. Культура. 2020. Вып. 2. С. 61-65.

Долгая осень 1830 года выдалась для А. С. Пушкина по-настоящему плодотворной. Вынужденный задержаться в Болдино из-за вспышки холеры, писатель создал ряд замечательных произведений, ставших впоследствии классическими. Среди них и окончание «Евгения Онегина», и «Маленькие трагедии», стихи, а также «Повести Белкина».

Последний сборник повествовал о жизни самых обыкновенных людей, но именно это вызывает у читателя сложность в понимании пушкинского мира. Однако это произведение вобрало в себя кладезь мыслей писателя об обыкновенной человеческой жизни, ее превратностях, изменениях судьбы, когда неожиданный случай диктует особые условия людям [1, с. 185]. 
А. С. Пушкин от имени вымышленного героя-рассказчика, некоего Ивана Петровича Белкина, рассказывает о жизни людей, их маленьких радостях, устремлениях, бедах и тревогах, при этом перемещая картину мира с реального пространства и времени в ирреальное. К тому же читатель не сразу замечает подобную повествовательную метаморфозу.

«Повести Белкина» изучаются в школе с 7/8-х по 9-е классы в отдельных повестях. И не всегда юный читатель осознает серьезность и глубокую содержательность художественного материала. Для разрешения этого вопроса мы считаем важным введение в школьную программу элективного курса по изучению «Повестей Белкина». Ведь прежде всего именно преподаванием литературы в школе можно воспитать образованное, интеллектуальное, разбирающееся во многих жизненных ситуациях новое поколение. Данный курс будет способствовать активизации познавательной деятельности учащихся, их способности к самостоятельному поиску ответов в решении образовательных задач, позволит расширить кругозор, отточить внимание, приведет в целом к процессу осмысленного чтения.

Для большей эффективности работу можно распланировать в несколько этапов, в каждом из которых юные читатели должны понять, что в «Повестях Белкина» Пушкин противопоставляет реальную жизнь, отношение человека к ней романтическому взгляду на действительность. При этом ни в коем случае нельзя дать осознать таким читателям, что писатель вообще отказывает человеку в вере в лучшее, прекрасное. Надо остановиться именно на тех страницах в произведении, где А. С. Пушкин намеренно подчеркивает ошибочность в излишне романтическом принятии мира.

«Повести Белкина» должны раскрыть естественность картины несоответствия разных пространственно-временных координат или планов в жизни людей. Тогда как классическая русская литература и по-прежнему, и по-новому открывает многие неизвестные страницы «давно забытого старого». В этом плане справедливо замечание литературоведов, что в данном произведении А. С. Пушкин не случайно обращает внимание на тот образ жизни и поступки людей, которые сформировались за чертой столичного светского бытия [2, с. 7]. Каждая повесть в данном цикле, расположенная в следующей композиционно-сюжетной линии: «Выстрел», «Метель», «Гробовщик», «Станционный смотритель», «Барышня-крестьянка», призвана раскрыть локальность, узость, мелочность одного пространственно-временного плана жизни на фоне вечности «большой» картины всего мира. Отсюда легкая, в какой-то степени укорительная ирония писателя над романтическим восприятием мира провинциальных людей.

При этом Пушкин не трогает добрых, душевных качеств человека. Они необходимы людям. Однако от наивности восприятия мира, его ожесточенности, озлобленности и мелочности, которые возникают как раз в этом локальном пространственно-временном континууме, людям освобождаться надо. Именно в этом и состоит идея всего цикла. Это и должен понять современный читатель.

В каждой повести можно найти подобное несоответствие в восприятии мира. Так, в повести «Выстрел» стоит остановиться на некоторых сведениях о дуэли. В частности, что в сознании людей дуэль долгое время относилась к понятию чести. Позже произошла трансформация этого в ложное представление о ценно- 
Цьљенова Е. Б., Данчинова М. Д., Художественный мир произведений А. С. Пушкина «Повести Белкина» в осмыслении юного читателя

стях жизни. Дуэль, по замыслам Пушкина, заслонила в сознании людей все краски самой жизни, ее настоящие истоки, превратила человека в погоню за мнимой целью. Чего добился Сильвио? Он по-настоящему потерял собственный смысл жизни, ежечасно думая о своем праве на выстрел.

Изучение повести «Метель» дает возможность познакомиться с композицией Г. Свиридова «Метель» и стихотворением Пушкина «Бесы». Здесь, с позиции исследователя, необходимо вести речь о превратностях судьбы человека из-за любви. Именно эту тему развивают фабула и сюжет повести [3, с. 4]. Пушкин в данном произведении размышляет о надуманности человеком себе высоких чувств под влиянием различных факторов. Именно здесь мы встречаемся с серьезным, трагическим и легким, ироническим планами жизни. Такое соединение в повести не случайно. С позиции литературоведов, человек ни в коем случае не должен подменять свою жизнь, собственные планы, цели уже готовыми формулами поведения, данными в разных источниках, в том числе в первую очередь в книгах [4].

Никакие книги не могут заменить яркость и многообразие настоящей жизни: ее радости и печали, житейские мелочи и глобальные конфликты, закономерности и неожиданности. Писатель утверждает, что жизнь не только непостижима до конца, но и безумно интересна. Однако понять это сможет лишь тот, кто доверится ей, а не будет пытаться строить свое существование согласно штампам и клише романтической литературы.

Отсюда трагичность жизни Марьи Гавриловны, Бурмина, решившегося подыграть в ту злосчастную минуту в церкви таинственной незнакомке. И как знак судьбы, как наказание - его любовь к Марье Гавриловне. Герой мучается, боится признаться долгое время даже себе. Современного читателя должна остановить, образумить идея Пушкина о невозможности игры в самую жизнь. Никак, никакими средствами, элементами нельзя заслоняться от естественного течения самой жизни.

В повести «Гробовщик» Пушкин словно сгущает этот идейный посыл. Мало того, что человек в реальном мире совершает роковые ошибки, из-за которых он испытывает трудности, так еще и «открытие» ирреального плана может окончательно погубить людей. На примере героя Андрияна Прохорова, открывшего в отчаянном мелком ожесточении «портал» ирреального, Пушкин предупреждает о недопущении подобного. В то же время писатель заставляет серьезно подумать людей о существовании многомерности и многоплановости мира, о чем «маленькие» люди совершенно не подозревают. Современному юному читателю подобное знание вполне понятно, так как «открытие нескольких окон» и существование в них для молодого поколения не секрет.

Повести «Станционный смотритель» и «Барышня-крестьянка» подводят своего рода итог серьезному разговору Пушкина с читателем о жизни, возможностях мирного - гармоничного - сосуществования многих людей в одном пространственно-временном континууме. При этом Пушкин не случайно к этому подходит с размышлений о взаимоотношениях как родных в одной семье («Станционный смотритель»), так и разных людей («Барышня-крестьянка»). Эгоистичность одних, необдуманность поступков других могут привести к не- 
разрешимой трагедии, когда навсегда могут порваться кровные родственные связи. Мотив притчи о блудном сыне в «Станционном смотрителе» призван не допустить подобный разрыв. А излишняя игра в «жизнь», как в «Барышнекрестьянке», может завести людей в сложные «дебри» человеческих отношений.

Таким образом, цикл повестей позволяет раскрыть перед взором юного читателя обширную панораму обыкновенной человеческой жизни со многими сложными, порой неразрешимыми, а то и трагичными случаями. В этом плане система действий при воспитании молодого поколения на разных стадиях изучения произведения должна быть направлена на развитие именно осмысленного чтения учащихся, их заинтересованности, готовности к сотрудничеству. Нельзя забывать о собственной инициативе читателей, их самостоятельности при выборе заданий или формировании идейных задумок, выполнении различных проектов, возможностях творческого потенциала.

\section{Литература}

1. Иванчикова Е. А. Рассказчик в повествовательной структуре произведений Достоевского // Ф. М. Достоевский: материалы исследования. М.: ИРЯ РАН, 1994. С. 41-50.

2. Кожевникова Н.А. Типы повествования в русской литературе XIX-XX вв. М.: ИРЯ PAH, 1994. 333 c.

3. Каспржак А. Г. Элективные курсы - ответ на запросы ученика и учителя, семьи и государства // Директор школы. 2006. № 1. С. 3-9.

4. Ковзик Т. М. Художественная литература как искусство слова [Электронный ресурс]. URL: http://way26.ucoz.net/index/literatura_kak_iskusstvo_slova/0-54 (дата обращения: 16.08.2020).

5. Влащенко В. И. Загадка «Метели» // Русская словесность. 2000. № 1. С. 43-49.

6. Зубарева В. К. «Повести Белкина»: литература «действительности» и маслит // Вопросы литературы. 2019. № 5. С. 24-74

7. Смирнова Н. Н. Изображаемое и рассказываемое в прозе Пушкина. «Повести Белкина». М.: Канон, 2020. 192 с.

8. Кулыгина А. Г. Поэтика портрета в «Повестях Белкина» А. С. Пушкина: дис. ... канд. филол. наук. Нижний Новгород: Изд-во Нижегородского госуниверситета, 2008. $203 \mathrm{c}$.

9. Маркович В. М. «Повести Белкина» и литературный контекст // Пушкин: исследования и материалы. Л.: Наука, 1989. С. 63-87.

10. Пушкин А. С. Повести Белкина. М., 1989. 134 с.

\section{ARTISTIC WORLD OF "THE BELKIN TALES" BY A. S. PUSHKIN IN THE COMPREHENSION OF YOUNG READERS}

Elena B. Tsydenova

Cand. for a Master's Degree,

Institute of Philology and Mass Communications

Dorzhi Banzarov Buryat State University

24a Smolina St., Ulan-Ude 670000, Russia

tsdenova@mail.ru 
Цьљенова Е. Б., Данчинова М. Д., Художественный мир произведений А. С. Пушкина «Повести Белкина» в осмыслении юного читателя

Mariya D. Danchinova

Cand. Sci. (Phil.), A/Prof.,

Institute of Philology and Mass Communications

Dorzhi Banzarov Buryat State University

24 a, st. Smolina, Ulan-Ude 670000, Russia

marinadan67@mail.ru

Abstract. The article discusses the artistic world of "The Belkin Tales" by A. S. Pushkin. The originality of the space-time picture of the world is shown through the compositional interaction of stories, figurative system or plot line. The worldview is revealed in the form of a narrative. In this regard, the writer goes to the brink of universal human foundations. From the standpoint of an artist, everything in human life is not accidental. A chain of interrelated events affects a person's life in all respects, including various events in society, seemingly unexpected meetings with people, violations of many ethical norms that influence the life of a person, and many religious and cultural values established by each nation. The author artistically warns people against a spiritless, consumerist attitude towards the whole world. The writer's stories calls to think about the consequences of the moral decline of people, their egoistic attitude towards each other.

Keywords: composition; picture; world; hero; space; image; system. 